\title{
Differential ferrioxamine test in idiopathic haemochromatosis and transfusional haemosiderosis
}

\author{
J. FIELDING, M. C. O'SHAUGHNESSY, AND GILLIAN M. BRUNSTRÖM
}

From Paddington General Hospital, London

SYNOPSIS The differential ferrioxamine test measures the amount of body iron as ferrioxamine (Fv) chelated by a standard dose of desferrioxamine.

Five patients with untreated, uncomplicated idiopathic haemochromatosis and one with transfusion haemosiderosis gave Fv in the range 1,948 to $2,462 \mu \mathrm{g} . / \mathrm{kg}$. (normal 110 to 500 ). One case of transfusion haemochromatosis with haemolytic anaemia and renal failure gave an Fv value of $8,019 \mu \mathrm{g} . / \mathrm{kg}$. Four patients with idiopathic haemochromatosis after therapeutic venesection gave Fv values of 212 to $885 \mu \mathrm{g}$. $/ \mathrm{kg}$. One relative with a value for Fv of $776 \mu \mathrm{g} . / \mathrm{kg}$. was shown to have early cirrhosis by liver biopsy. Serial Fv measurement after venesection in this patient provided a preliminary assessment of the relationship between Fv values and available iron stores up to about $2,000 \mathrm{mg}$. iron. This relationship applies only when red cell survival is normal. Approximate figures for the range of available storage iron in 31 healthy men are deduced, namely, $200 \mathrm{mg}$. to $1,000 \mathrm{mg}$. ( 3 to $14 \mathrm{mg}$. $/ \mathrm{kg}$.).

The test should prove useful in the diagnosis of iron overload, in the screening of relatives for early haemochromatosis, and in the management of iron storage diseases.

The introduction of chelating agents of low molecular weight which bind iron in vivo and result in the excretion of an iron chelate in the urine has suggested several procedures as aids to diagnosis and control of therapy in haemochromatosis and allied conditions. Diethylenetriamine penta acetic acid (DPTA) in doses of $1 \mathrm{~g}$. has been infused intravenously over 30 minutes and the urinary output of iron measured in the subsequent five or six hours (Walsh, Perkins, Blackburn, Sanford, and Cantrill, 1963; Lloyd, Powell, and Thomas, 1964). Desferrioxamine, from 500 to $1,000 \mathrm{mg}$., has been injected intramuscularly with measurement of the 24-hour urinary iron output (Keberle, 1964; Ploem, Verloop, and Wael, 1964). Sometimes comparison with a 24-hour urinary iron output without a chelator has been advised.

The differential ferrioxamine test (Fielding, 1965) measures the amount of body iron chelated by desferrioxamine. It has some advantages over previously described tests: some biological variables have been reduced by using test doses adjusted to body weight and expressing the results in terms of body weight; the chemical estimation determines urinary ferrioxamine by a simple and reproducible method, avoiding the often variable estimation of urinary iron, the data permitting not only the proportion excreted in an arbitrary time to be calculated but also body iron chelated by the test dose. The timing of collecting specimens or urine is not critical and the measurement of iron chelation is possible in the presence of renal failure.

Desferrioxamine is a more specific chelator of trivalent iron and seems less toxic when used in longterm therapy than other chelators. Tests based on desferrioxamine are therefore preferred since they offer a guide to its therapeutic efficiency in promoting iron excretion in each case.

The present paper describes the results of the test in certain patients with iron storage disease.

METHODS

The differential ferrioxamine test is based on the chelation of body iron by desferrioxamine (Fig. 1). Briefly, it consists of an intravenous injection of a standard bodyweight dose, $500 \mathrm{mg}$. $/ 60 \mathrm{~kg}$., of desferrioxamine methane sulphonate (Desferal, Ciba), together with a body-weight dose of ferrioxamine labelled with $2 \mu \mathrm{C}^{59} \mathrm{Fe}$. A single sixhour specimen of urine is collected. The proportion of 
injected ferrioxamine excreted in six hours (Fex \%) is estimated as ${ }^{59} \mathrm{Fe}$ and is also expressed as the amount of injected ferrioxamine excreted (Fex). The total amount of ferrioxamine in the urine $(\mathrm{Ft})$ is estimated chemically (Fielding and Brunström, 1964). The estimations are simple and take only some minutes. The difference, $\mathrm{Fd}=\mathrm{Ft}-\mathrm{Fex}$, measures the amount of ferrioxamine excreted which has been derived from chelation of body iron. Fd (mg.) corresponds to the amount of ferrioxamine (or of iron) excreted in six hours atter a standard intravenous dose of desferrioxamine alone, and therefore is a measure of the therapeutic effectiveness of the drug in the case under investigation.

Since the excretion from a known intravenous dose of ferrioxamine (F) is known, the total amount of ferrioxamine formed from body iron (Fv) is deduced by simple proportion.

$$
\mathrm{Fv}=\frac{\mathrm{Fd}}{\mathrm{Fex}} \times \mathrm{F} \mathrm{mg.}=\frac{\mathrm{Fd}}{\mathrm{Fex}} \times 833 \mu \mathrm{g} . / \mathrm{kg} .
$$

When simplified in terms of the observations made, this expression becomes

Fv $\mu$ g. $/$ kg. $=\left[\begin{array}{c}\text { ferrioxamine in 6-hr. urine (mg. \%) } \\ \frac{\times{ }^{59} \mathrm{Fe} \text { in test dose }(\mathrm{cpm} / \mathrm{ml} .)}{{ }^{59} \mathrm{Fe} \text { in 6-hr. urine (cpm/ml.) }}\end{array}\right]-833$

Serum iron was determined by the method of Kok and Wild (1960) and serum total iron-binding capacity was determined by the absorption of excess ferric chloride with magnesium carbonate (Ramsay, 1957).

The grading of stainable iron in the liver follows that of Scheuer, Williams, and Muir (1962).

In one patient (V.L.) with a minor degree of iron overload, the amount of storage iron that could be mobilized was calculated during repeated venesection following the principle of Haskins, Stevens, Finch, and Finch (1952). The calculation made the following assumptions: blood volume, $70 \mathrm{ml} . / \mathrm{kg}$.; iron content of haemoglobin, $0.34 \mathrm{~g} \%$; menstrual blood loss, $30 \mathrm{mg}$. iron per month; available iron stores nil when $\mathrm{Fv}=88 \mu \mathrm{g}$. $/ \mathrm{kg}$. (Fielding, O'Shaughnessy, and Brunström, 1965).

\section{CLINICAL MATERIAL}

Twelve patients with iron storage disease were tested; five with untreated idiopathic haemochromatosis; four wi idiopathic haemochromatosis who had been venesected for varying periods of time; one patient with a mingr degree of iron overload identified in a family study of $\mathrm{f}^{\mathrm{a}}$ patient with idiopathic haemochromatosis and two patients with defective erythrogenesis who had been transfused over many years resulting in an iron overload of not less than $40 \mathrm{~g}$. iron. One of the latter patierfs (J.W.) was in chronic renal failure, possibly due to pyelonephritis, with a blood urea level of 100 to $150 \mathrm{mg} . / 100$ $\mathrm{ml}$. The anaemia in this patient was complicated byca marked haemolytic element, with mean red cell survival $\overrightarrow{\mathrm{g}}$ 20 days.

The results in these patients are compared with those 31 healthy men (medical students and hospital employeess) previously described (Fielding et al., 1965).

\section{RESULTS}

FV IN NORMAL MEN In 31 healthy men, Fv, the amount of ferrioxamine formed in vivo by chelation of body iron after a standard dose of desferrioxami ranged from 109 to $498 \mu \mathrm{g}$. $/ \mathrm{kg}$. There is a suggestion of bimodal distribution among these normal men, one subgroup with an Fv value of 110 to $200 \mu \mathrm{g}$. $/ \mathrm{kg}$. and another subgroup 250 to $500 \mu \mathrm{g} . / \mathrm{kg}$.

FV IN UNTREATED IDIOPATHIC HAEMOCHROMATOSIS

five patients $\mathrm{Fv}$ values varied from 1,992 to 2,4 $\mu \mathrm{g} . / \mathrm{kg}$. (Table I). Since ferrioxamine contaigis approximately one tenth its weight of iron, this equivalent to the mobilization of about 0.2 to $0.25 \mathrm{~mm}$. iron per kg. body weight. Figure 2 shows the pattern of excretion in four of these cases which were studied by observations on two-hourly uringe specimens.

FV IN VENESECTED HAEMOCHROMATOSIS Of foğ patients with idiopathic haemochromatosis who had undergone therapeutic venesection, two had Ev values above the normal range, 885 and $777 \mu \mathrm{g} . / \mathrm{kg}$; of these only one had a high serum iron level and fully saturated binding capacity. In two patients Fv value was in the normal range, with low serum iron levels and less than $20 \%$ saturation of bindiog capacity. Only one patient among the venesectid patients had a successful needle liver biopsy at the time of the test (Fv $346 \mu \mathrm{g} . / \mathrm{kg}$.), which showed excess of haemosiderin in the fibrous tissue of cirrhotic liver but without parenchymal haemesiderin.

FV IN TRANSFUSION IRON OVERLOAD Both patients with defects of erythrogenesis gave high $\mathrm{Fv}$ value्s, 1,948 and $8,019 \mu \mathrm{g} . / \mathrm{kg}$. The first is close to the valuess found in untreated haemochromatosis; the second patient (J.W.) had a short red cell life and was $m$ 
TABLE I

\begin{tabular}{|c|c|c|c|c|c|c|c|c|c|}
\hline \multirow[t]{2}{*}{ Case } & \multirow{2}{*}{$\begin{array}{l}\text { Sex } \\
\text { Age }\end{array}$} & \multirow[t]{2}{*}{ Diagnosis } & \multirow{2}{*}{$\begin{array}{l}\mathrm{Hb} \\
(\mathrm{g} . / 100 \mathrm{ml} .)\end{array}$} & \multirow{2}{*}{$\begin{array}{l}\text { Serum } \\
\text { Fe/Total } \\
\text { Iron-binding } \\
\text { Capacity } \\
(\mu \mathrm{g} . / 100 \mathrm{ml} .)\end{array}$} & \multirow{2}{*}{$\begin{array}{l}\text { Glucose } \\
\text { Tolerance } \\
\text { Test }\end{array}$} & \multicolumn{2}{|c|}{ Liver Biopsy } & \multirow{2}{*}{$\begin{array}{l}\text { Fex } \\
(\%)\end{array}$} & \multirow{2}{*}{$\begin{array}{l}F v^{3} \\
(\mu g . / k g .)\end{array}$} \\
\hline & & & & & & Fe Grade & Cirrhosis & & \\
\hline $\begin{array}{l}\text { S.M. } \\
\text { C.J. } \\
\text { A.G. } \\
\text { S.B. } \\
\text { M.D. } \\
\text { J.D. } \\
\text { J.W. }\end{array}$ & $\begin{array}{l}\text { M, } 47 \\
M, 64 \\
M, 50 \\
M, 71 \\
M, 41 \\
M, 18 \\
\text { F, 25 }\end{array}$ & $\begin{array}{l}\text { Untreated haemochromatosis } \\
\text { Untreated haemochromatosis } \\
\text { Untreated haemochromatosis } \\
\text { Untreated haemochromatosis } \\
\text { Untreated haemochromatosis } \\
\text { Transfusion haemosiderosis } \\
\text { Transfusion haemochromatosis }\end{array}$ & $\begin{array}{r}11 \cdot 8 \\
12 \cdot 9 \\
11 \cdot 8 \\
14 \cdot 7 \\
12 \cdot 8 \\
6 \cdot 9 \\
5 \cdot 0\end{array}$ & $\begin{array}{l}158 / 344 \\
210 / 213 \\
200 / 465 \\
240 / 248 \\
268 / 268 \\
305 / 330 \\
335 / 342\end{array}$ & $\begin{array}{l}\text { Diabetic } \\
\text { Diabetic } \\
\text { Diabetic } \\
\text { Diabetic } \\
\text { Prediabetic } \\
\text { Normal } \\
\text { Diabetic }\end{array}$ & $\begin{array}{l}++++ \\
++++ \\
++++ \\
++++ \\
++++\end{array}$ & $\begin{array}{l}+++ \\
+++ \\
+++ \\
+++ \\
+++ \\
\end{array}$ & $\begin{array}{l}50 \\
51 \\
64 \\
51 \\
51 \\
90 \\
10^{2}\end{array}$ & $\begin{array}{l}2,055 \\
2,090 \\
2,148 \\
2,462 \\
1,992 \\
1,948 \\
8,019\end{array}$ \\
\hline $\begin{array}{l}\text { T.D. }{ }^{1} \\
\text { B.A. } \\
\text { W.W. }{ }^{1} \\
\text { C.R. }\end{array}$ & $\begin{array}{l}\text { M, } 57 \\
\text { F, } 52 \\
\text { M. } 66 \\
\text { M, } 45\end{array}$ & $\begin{array}{l}\text { Venesected haemochromatosis } \\
\text { Venesected haemochromatosis } \\
\text { Venesected haemochromatosis } \\
\text { Venesected haemochromatosis }\end{array}$ & $\begin{array}{l}16 \cdot 4 \\
12 \cdot 6 \\
13 \cdot 4 \\
12 \cdot 2\end{array}$ & $\begin{array}{r}280 / 284 \\
114 / 390 \\
56 / 374 \\
53 / 324\end{array}$ & $\begin{array}{l}\text { Diabetic } \\
\text { Diabetic } \\
\text { Normal } \\
\text { Diabetic }\end{array}$ & + & +++ & $\begin{array}{l}25 \\
37 \\
31 \\
45\end{array}$ & $\begin{array}{l}885 \\
777 \\
346 \\
212\end{array}$ \\
\hline V.L. & F, 42 & Early haemochromatosis & $15 \cdot 7$ & $225 / 225$ & Normal & ++ & + & 58 & 776 \\
\hline
\end{tabular}

N.D. = not done

${ }^{1}$ Liver biopsy at first diagnosis gave Fe grade ++++ , cirrhosis $+++{ }^{2}$ Chronic renal failure ${ }^{3} \mathrm{Fv}$ range in normal men, $110-500$.

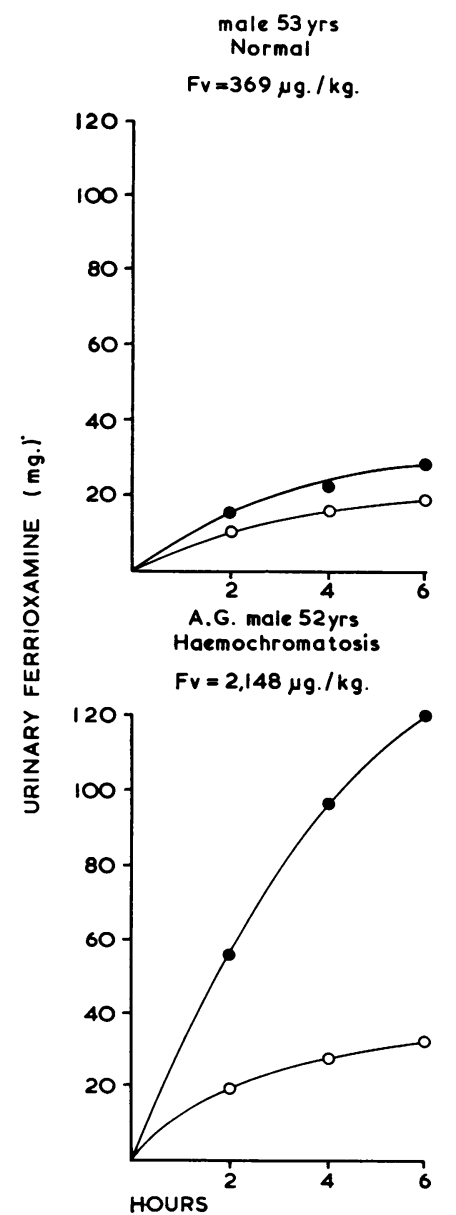

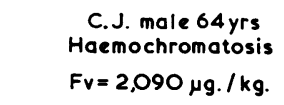

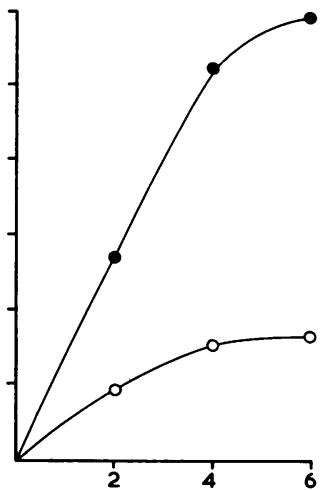

J.D. male 18 yrs

Erythrogenesis imperfecta Transfusional haemosiderosis

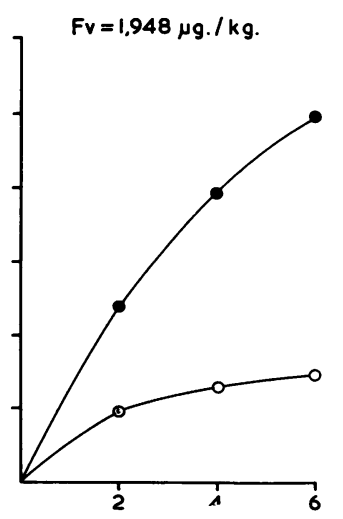

S.B. male 71 yrs

Hoemochromatosis

$F v=2,462 \mu \mathrm{g} . / \mathrm{kg}$.

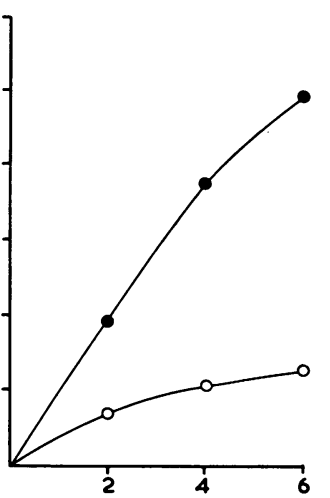

J.W. female $25 y r s$

Erythrogenesis imperfecta

Transfusional haemochromatosis

Haemolytic anaemia

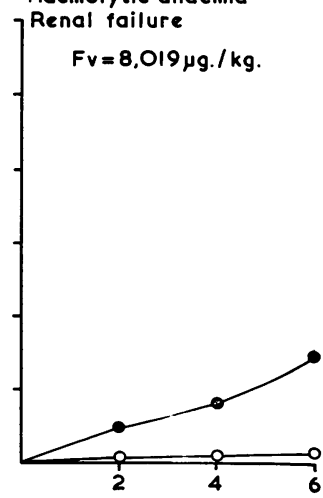

S.M. male $47 y$ yrs Hoemochromatosis

$F v=2,055 \mu \mathrm{g} . / \mathrm{kg}$.

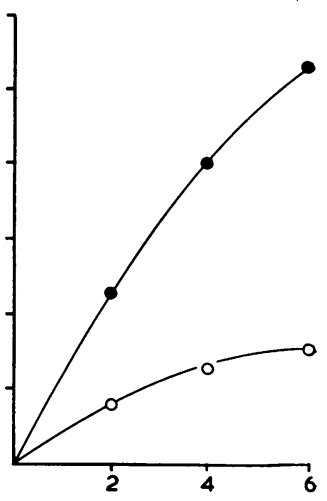

FIG. 2. Pattern of ferrioxamine excretion during differential ferrioxamine test. Solid dots $=F t$, total ferrioxamine excretion by chemical assay; open circles $=$ Fex, amount of ferrioxamine excreted from injected dose by ${ }^{59} \mathrm{Fe}$ assay. $\mathrm{A}$ two-hourly study was not made in patient $J$. D. (Table I). 
TABLE II

\begin{tabular}{|c|c|c|c|c|c|c|}
\hline \multirow[b]{2}{*}{ Date } & \multicolumn{5}{|c|}{ SERIAL FV DURING PHLEBOTOMY } & \multirow[b]{2}{*}{$\begin{array}{l}F v \\
(\mu g \cdot / k g .)\end{array}$} \\
\hline & $H b(g . / 100 \mathrm{ml})$. & $\begin{array}{l}\text { Serum } \\
\text { Fe/Total Iron-binding Capacity } \\
(\mu \mathrm{g} . / 100 \mathrm{ml} .)\end{array}$ & $\begin{array}{l}\text { Liver Biopsy } \\
\text { (Fe grade) }\end{array}$ & $\begin{array}{l}\text { Fe Removed by } \\
\text { Phlebotomy (mg.) }\end{array}$ & $\begin{array}{l}\text { Fex } \\
(\%)\end{array}$ & \\
\hline $\begin{array}{r}28.10 .64 \\
8.2 .65 \\
14.4 .65 \\
27.5 .65\end{array}$ & $\begin{array}{l}15 \cdot 7 \\
15 \cdot 4 \\
13 \cdot 8 \\
13 \cdot 1\end{array}$ & $\begin{array}{r}225 / 225 \\
272 / 272 \\
155 / 390 \\
65 / 414\end{array}$ & ++ & $\begin{array}{r}0 \\
1,040 \\
2,333 \\
2,960\end{array}$ & $\begin{array}{l}58 \\
46 \\
44 \\
44\end{array}$ & $\begin{array}{r}776 \\
576 \\
190 \\
88\end{array}$ \\
\hline
\end{tabular}

TABLE III

FV AND STORAGE IRON

\begin{tabular}{|c|c|c|c|c|c|c|c|c|c|}
\hline \multirow[t]{2}{*}{ Date } & \multirow[t]{2}{*}{$\begin{array}{l}\mathrm{Hb} \\
(\mathrm{g} . / 100 \mathrm{ml} .)\end{array}$} & \multirow[t]{2}{*}{$\begin{array}{l}F v \\
(\mu g . / k g .)\end{array}$} & \multirow{2}{*}{$\begin{array}{l}\text { Fe Removed } \\
\text { at Phlebotomy } \\
\text { ( } m g .)\end{array}$} & \multirow[t]{2}{*}{$\begin{array}{l}\text { Hb Deficit as } \\
\mathrm{Fe}(\mathrm{mg} .)\end{array}$} & \multirow[t]{2}{*}{$\begin{array}{l}\text { Menstrual Loss } \\
\text { of Fe (mg.) }\end{array}$} & \multicolumn{2}{|c|}{$\begin{array}{l}\text { Fe Removed from Stores }{ }^{1} \\
\text { (mg.) }\end{array}$} & \multicolumn{2}{|c|}{$\begin{array}{l}\text { Available Storage Fe } \\
\text { (mg.) }\end{array}$} \\
\hline & & & & & & $A$ & $B$ & $A$ & $B$ \\
\hline $\begin{array}{r}28.10 .64 \\
8.2 .65 \\
14.4 .65 \\
27.5 .65\end{array}$ & $\begin{array}{l}15 \cdot 7 \\
15 \cdot 4 \\
13 \cdot 8 \\
13 \cdot 1\end{array}$ & $\begin{array}{r}776 \\
576 \\
190 \\
88\end{array}$ & $\begin{array}{r}0 \\
1,040 \\
2,330 \\
2,960\end{array}$ & $\begin{array}{r}0 \\
53 \\
333 \\
456\end{array}$ & $\begin{array}{r}0 \\
90 \\
150 \\
180\end{array}$ & $\begin{array}{r}0 \\
771 \\
1,649 \\
2,060\end{array}$ & $\begin{array}{r}0 \\
567 \\
1,315 \\
1,644\end{array}$ & $\begin{array}{r}2,060 \\
1,289 \\
411 \\
0\end{array}$ & $\begin{array}{r}1,644 \\
1,077 \\
329 \\
0\end{array}$ \\
\hline
\end{tabular}

${ }^{1} \mathrm{~A}$ : Corrected for excess absorption over excretion of $3 \mathrm{mg}$. Fe per day; B, for $5 \mathrm{mg}$. Fe per day excess.

chronic renal failure. Both these factors could contribute to the exceptionally high chelation and are further discussed below. The pattern of excretion in these cases is also shown in Figure 2.

SERIAL FV DURING VENESECTION V.L. is the sister of S.M., a patient with untreated haemochromatosis. Her serum iron level was $225 \mu \mathrm{g} . / 100 \mathrm{ml}$. and the binding capacity was fully saturated; a liver biopsy at this time showed early cirrhosis with $2+$ histochemical iron, which was distributed in parenchyma, in reticulo-endothelium, and in periportal fibrous tissue. The Fv value, $776 \mu \mathrm{g}$. $/ \mathrm{kg}$., was above the normal range. She was venesected over a period of seven months during which $2,960 \mathrm{mg}$. iron was removed, and the Fv value fell progressively to 88 $\mu \mathrm{g} . / \mathrm{kg}$. (Table II). By this time the haemoglobin had fallen from 15.7 to $13.1 \mathrm{~g} . / 100 \mathrm{ml}$., serum iron and total iron-binding capacity were characteristic of iron deficiency, and liver biopsy showed no reticuloendothelial haemosiderin, minimally in the parenchyma, but there remained an excess of haemosiderin in fibrous tissue assessed as $1+$.

Storage iron was calculated from the venesection data (Table III) and is compared with the corresponding Fv values in Figure 3.

EXCRETION OF FERRIOXAMINE (FEX \%) The proportion of an intravenous dose of ${ }^{59} \mathrm{Fe}$-ferrioxamine excreted in the urine in six hours in 59 out of 61 normal men and women ranged from 30 to $53 \%$; in two normal men, aged 63 and 76 , it was $20 \%$, and in these older subjects some degree of renal insufficiency may well have been present (Fig. 4).
In seven cases of untreated iron storage disease $\overrightarrow{0}$ Fex \% ranged from 50 to $90 \%$; in four patients whoo had undergone therapeutic venesection Fex \% ranged from 25 to $45 \%$; in one patient with transfusional haemochromatosis in chronic renal failure, Fex $\%$ was $10 \%$. Thus in untreated, uncomplicated iron storage disease, Fex $\%$ ranges from high normal $\mathrm{Q}$

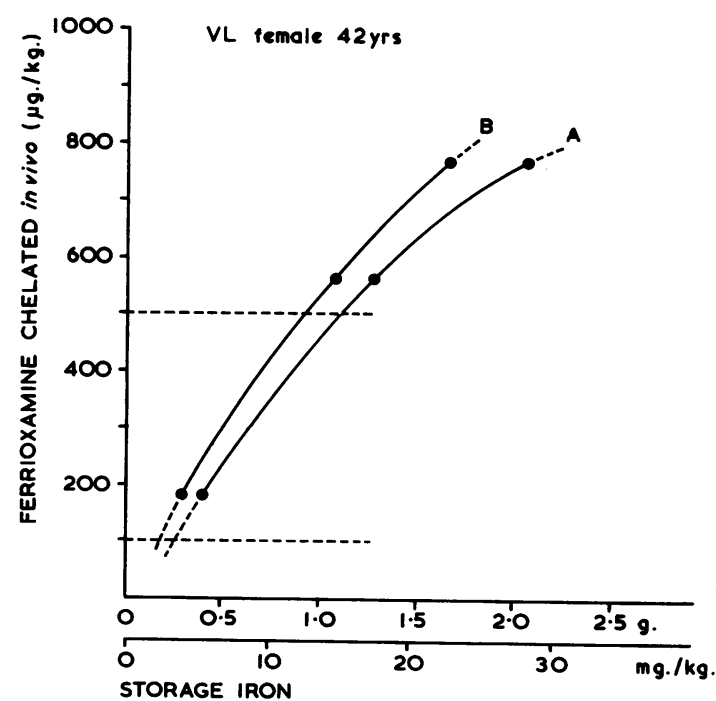

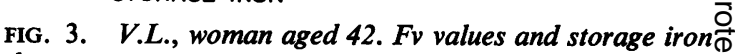
during venesection. $A$, calculation corrected for excess absorption over excretion of $3 \mathrm{mg}$. Fe per day; $B$, corrected for $5 \mathrm{mg}$. Fe per day excess. The horizontal interruptedo lines show the limits of $F v$ in normal men. 


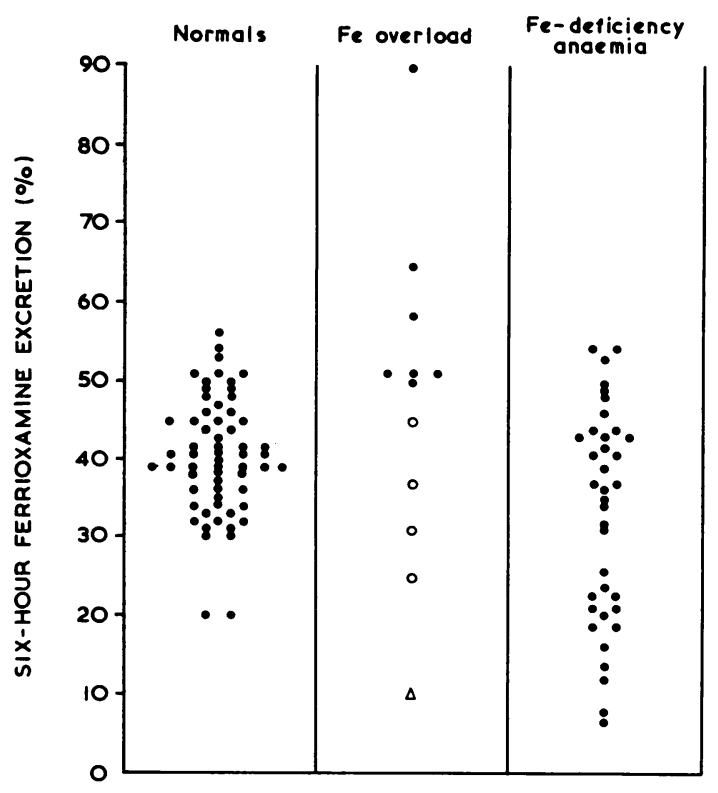

FIG. 4. Six-hour urinary excretion of ferrioxamine as a percentage of standard intravenous dose. In centre column, solid dots = untreated haemochromatosis, open circles $=$ venesected haemochromatosis, $\Delta=$ transfusion haemochromatosis with renal failure.

to as high as $90 \%$, and falls as iron stores are reduced. This contrasts with iron-deficiency anaemia in which Fex \% ranges in the opposite direction from normal to as low as $10 \%$. The significance of these patterns of excretion is discussed below.

\section{DISCUSSION}

A striking feature of the differential ferrioxamine test in six patients with uncomplicated untreated haemochromatosis is the narrow range of $\mathrm{Fv}$ values. The ratio of the highest, $2,462 \mu \mathrm{g}$. $/ \mathrm{kg}$., to the lowest, $1,948 \mu \mathrm{g} . / \mathrm{kg}$., is $1 \cdot 26$. This compares with a high to low ratio of 4.0 in the DPTA test on a similar number of patients (Walsh et al., 1963). Since it is improbable that all untreated patients with haemochromatosis have the same amount of storage iron per kilogram body weight, it is likely that in iron overloading to this extent the dose of desferrioxamine used, $8.33 \mathrm{mg}$. $/ \mathrm{kg}$., is chelating to its maximum capacity in vivo, when the course of iron presented to it is ferritin-haemosiderin. Under these conditions 0.2 to $0.25 \mathrm{mg}$. iron per kilogram body weight is mobilized by the test dose of desferrioxamine, i.e., about a quarter of its maximum capacity in vitro.

The narrow range of $\mathrm{Fv}$ in uncomplicated haemochromatosis suggests that the test should be a useful diagnostic procedure.
Iron may also be mobilized by desferrioxamine from sources other than or in addition to ferritinhaemosiderin stores. It has been shown that high chelation values are also obtained in pernicious anaemia and some haemolytic anaemias, in which the main source of chelated iron is considered to be iron newly released from haem (Fielding, 1965).

These observations may explain the results in the patient J.W., who had defective erythrogenesis, transfusional haemochromatosis, haemolytic anaemia, and chronic renal failure. She also produced the exceptionally high value for Fv of $8,019 \mu \mathrm{g}$. $/ \mathrm{kg}$. This is about $85 \%$ of the maximum chelation capacity of the dose of desferrioxamine in vitro. Both iron overload and the haemolytic anaemia could provide excess of available iron for chelation and contribute to the high Fv value. Renal failure, by delaying excretion, may have prolonged high blood levels of desferrioxamine and also contributed to the high chelation obtained. Only $2.5 \%$ of the desferrioxamine dose was recovered from the urine in this case compared with 40 to $65 \%$ in normal subjects.

SIGNIFICANCE OF Fex \% The two metabolic pathways of ferrioxamine which are known with certainty are urinary excretion and the utilization of a proportion of ferrioxamine iron for haemoglobin synthesis (Bannerman, Callender, and Williams, 1962; Hallberg, 1964). Although ferrioxamine has a high stability constant in vitro, the avidity of tissue receptors at erythropoietic sites is effective in detaching iron from the chelator. An inverse relationship is therefore to be expected between the amount of urinary excretion and the amount of erythropoietic uptake of ferrioxamine iron. Thus where erythroid avidity is high, as in iron-deficiency anaemia and in haemolytic anaemias, urinary excretion tends to be low. In iron overload marrow avidity for iron is replete from endogenous sources and therefore urinary excretion tends to be high. The highest urinary excretion of ferrioxamine observed was $90 \%$ in six hours, in a patient (J.D.) with erythrogenesis imperfecta in whom there were no erythropoietic receptor sites.

However, in most cases the total of urinary excretion and utilization of ferrioxamine iron does not account for all ferrioxamine injected and there is possibly a third metabolic pathway not yet defined.

FV AND STORAGE IRON In the patient V.L. with minor iron overload, Fv values were progressively reduced as storage iron was removed during the course of phlebotomy. Following the principles of Haskins et al. (1952) the amount of storage iron was calculated from the phlebotomy data. Two values were calculated: the first assumed an excess of ab- 
sorption over excretion of $3 \mathrm{mg}$. a day (Haskins et al., 1952), and since this patient almost certainly has early haemochromatosis, the second value assumed an excess of $5 \mathrm{mg}$. per day (Crosby, Conrad, and Wheby, 1963). These limits as calculated and the corresponding Fv values are shown in Figure 3. The shape of the curve suggests that at the dose of desferrioxamine used, a limiting value for $F v$ is reached as iron stores increase. This is consistent with the results in untreated, uncomplicated haemochromatosis which show a small scatter of high values.

Figure 3 also shows that storage iron corresponding to the Fv range in normal men varies over a fivefold range, from approximately $200 \mathrm{mg}$. to $1,000 \mathrm{mg}$. ( 3 to $14 \mathrm{mg} . / \mathrm{kg}$.). The limits are not well defined and this must be a provisional assessment, based on a single study; nevertheless it emphasizes that the range of storage iron in normal healthy men is much wider than hitherto reported and often approaches iron depletion. A similar conclusion was drawn from a comparison of the test in normal men and irondeficiency anaemias (Fielding et al., 1965).

CONTROL OF VENESECTION THERAPY Only five patients who had undergone therapeutic venesection have been investigated so far, and these are too few for assessing the value of the test in controlling therapy. In two patients, W.W. and V.L., needle liver biopsy, repeated after venesection, showed an excess of haemosiderin in fibrous tissue, although parenchymal and reticulo-endothelial haemosiderin were almost depleted. In these cases haemoglobin had fallen and serum iron was normal or low. The corresponding $\mathrm{Fv}$ values indicated normal to low storage iron levels, and thus gave a better assessment of available iron at the time of the test than the liver biopsy.

The criteria for the amount of therapeutic venesection in haemochromatosis have yet to be firmly established. After large amounts of iron have been removed, anaemia and the signs of iron deficiency may be found when some parenchymal haemosiderino is still to be seen in the liver. This residual haemo siderin may be extremely difficult to mobilize (Frey Milne, Johnson, and Ebaugh, 1961; Finch ando Finch, 1955). The present findings indicate that histo-o chemical haemosiderin of grade $2+$ in the liver mays mean the presence of no more than a total of 2 to $3 \mathrm{~g}$. $\stackrel{0}{0}$ storage iron. It is doubtful therefore whether there is much to be gained by removing the last visible traces of liver haemosiderin, and, since Fv values provide $\mathrm{a}_{\rightarrow}^{\circ}$ better guide to available iron than liver biopsy, it $\vec{\omega}$ should also prove more useful in controlling vene-o section therapy. Further observations in venesected patients are required.

We wish to thank Professor W. Butterfield, Dr. C. Hinds-Howell, Dr. J. D. N. Nabarro, Professor P. L. Mollison, and Dr. Carmichael Young for agreeing too studies on their patients, the North West Metropolitan Regional Hospital Board for research grants, and Ciba Laboratories Ltd. for gifts of drugs and apparatus.

\section{REFERENCES}

Bannerman, R. M., Callender, S. T., and Williams, D. L. (1962). Brit. med. J., 2, 1573.

Crosby, W. H., Conrad, M. E. jr., and Wheby, M. S. (1963). Blood, 22, 429.

Fielding, J. (1965). J. clin. Path., 18, 88.

—, and Brunström, G. M. (1964). Ibid., 17, 395.

응 $2,9$.

Finch, S. C., and Finch, C. A. (1955). Medicine (Baltimore), 34, 381.

Frey, W. G., Milne, J., Johnson, G. B. Jr., and Ebaugh, F. G. Jr. (1961). New Engl. J. Med., 265, 7.

Hallberg, L. (1964). In Iron Metabolism, edited by F. Gross, p. 592.

Springer, Berlin.
Haskins, D., Stevens, A. R. Jr., Finch, S., and Finch, C. A. (1952). J官 clin. Invest., 31, 543. Keberle, H. (1964). In Iron metabolism, edited by F. Gross, p. $600 . \frac{\mathrm{C}}{\text { Springer, Berlin. }}$

Kok, D'A., and Wild, F. (1960). J. clin. Path., 13, 241.

Lloyd, H. M., Powell, L. W., and Thomas, M. J. (1964). Lancet, 2, $\frac{3}{3}$ 555.

Ploem, J. E., Verloop, M. C., and Wael, de J. (1964). Abstr. Proc. 10th Congr. int. Soc. Haemat. p. F19.

Ramsay, W. N. M. (1957). Clin. chim. Acta, 2, 221.

Scheuer, P. J., Williams, R., and Muir, A. R. (1962). J. Path. Bact., 84, 음

Walsh, R. J., Perkins, K. W., Blackburn, C. R. B., Sanford, R., and $\frac{D}{O}$ Cantrill, S. (1963). Aust. Ann. Med., 12, 192. 